Ludanyi, Andrew. "Blomqvist, Anders E. B., Constantin Iordachi, Balázs Trencsényi (eds.) 2013. Hungary and Romania Beyond National Narratives - Comparisons and Entanglements in Nationalisms Across the Globe." Hungarian Cultural Studies. e-Journal of the American Hungarian Educators Association, Volume 7 (2014): http://ahea.pitt.edu DOI: 10.5195/ahea.2014.153

\title{
Blomqvist, Anders E. B., Constantin Iordachi, Balázs Trencsényi (eds.) 2013. Hungary and Romania Beyond National Narratives - Comparisons and Entanglements in Nationalisms Across the Globe Vol. 10. Bern: Peter Lang. viii, 847 pp.
}

\section{Reviewed by: Andrew Ludanyi, Ohio Northern University}

Blomqvist, Iordachi and Trencsényi have produced a truly impressive compilation of scholarship on Romanian-Hungarian relations in their co-edited volume Hungary and Romania Beyond National Narratives. This book is volume 10 of the Peter Lang series on Nationalisms Across the Globe under the general editorship of Tomasz Kamusella and Krysztof Jaskulowski. It includes the studies of the three editors as well as those of seventeen other well-known scholars in the field. The collection has a selected bibliography (773-823), a useful summary of the scholarly backgrounds of the contributors (825-832), and an index (833-847) that is a further detailed guide to the dominant themes as outlined in the table of contents (v-viii).

The overall objective of this collection is to analyze Hungarian-Romanian relations "beyond national narratives" by comparing the recent history of the two nations, the two states and the two peoples via their "entanglements," meaning interface, conflicts and common culture and interests. Without delving into a critique of the individual essays in the volume, a preliminary critical observation is that the book lacks visual materials. If entanglement is a key concept, it should be demonstrated via maps and pictures, which would be indispensable for illustrating the extent of inter-relatedness and entanglement of Romanians and Hungarians over time, particularly in the context of the last two centuries. Especially with regard to the region of Erdély/Transylvania, a major "entanglement" area between the two countries, such artefacts should have also included tables providing the key census results of the past one-hundred and fifty years in this region. Additional visual documentation could have been provided by photoes of church buildings, statues and monuments of competing national heroes, the place-name competition for streets, squares and towns as well as the evolution of national flags as described in Judith Pál's article in the volume (93-125).

Turning our attention to the content of the book, we might ask to what extent it has succeeded in contributing "to the ongoing effort of overcoming the traditional ethnic-bound national narratives by rethinking the entangled history of Hungary and Romania" (9). As they point out in their introduction, the editors are aware that the interactions and the interdependence created by the entanglement of Romanians and Hungarians is not a new development, that it can be traced back to the origins of the self-definition of both experiences (9-15). To what extent, then, has this compilation of studies succeeded in overcoming the shortcomings of previous analyses? My answer is that some of the contributors have succeeded, while others have not. Due

$(\mathrm{cc}) \mathrm{BY}$

ULLS D-Serle
New articles in this journal are licensed under a Creative Commons Attribution 4.0 International License.

This journal is published by the University Library System of the University of Pittsburgh as part of its D-Scribe Digital Publishing Program and is cosponsored by the University of Pittsburgh Press 
Ludanyi, Andrew. "Blomqvist, Anders E. B., Constantin Iordachi, Balázs Trencsényi (eds.) 2013. Hungary and Romania Beyond National Narratives - Comparisons and Entanglements in Nationalisms Across the Globe." Hungarian Cultural Studies. e-Journal of the American Hungarian Educators Association, Volume 7 (2014): http://ahea.pitt.edu DOI: 10.5195/ahea.2014.153

to limitations of space one cannot critique all the essays. However, I will discuss the major contributions to this volume as well as reflect on some of their shortcomings.

With regard to the major positive contributions, the introductory essay of the editors and their individual studies deserve attention. These include Blomqvist's "Nationalizing Economic Entanglements, 1867-1940" (155-202), Trencsényi’s discussion of ideological commitments to nationalism following 1945 (515-568), and Iordachi's essay on the evolution of dual citizenship in both countries in 1945-2012 (711-771). Also of real substance is the excellent study by Sorin Mitu on how "images of hostility" are born or created; the fine comparative study of Keith Hitchins on "accomodation or separation" in the 1867-1918 and 1918-1940 periods, respectively; Martin Mevius' study on the "historiographical" disputes between Romanians and Hungarians in 1945-1989; Csaba Zahoran's comparative analysis of secondary historical sources; and Levente Salat's analysis of Romanian-Hungarian relations in the Post-Communist era. To these major contributions I would also add Zoltán Pálfy's and Lucian Nastasa's essays on comparative educational policies at the university level. The only reservation I have with the latter is that Nastasa ends his analysis with the merger of the Babes and Bolyai universities and thus gives up discussion of both the Ceausescu era and the consecutive post-1989 developments.

Sorrowfully, Blomqvist's article on the region of Erdély/Transuylvania as a borderland deserves some critical remarks, too. His approach uses a flawed analogy to describe Transylvania, as he designates the region as a "borderland" without first clarifying what "borderland" means in this case. Does it refer to all of Transylvania or just to its border strip with present-day Hungary, or that with Romania prior to 1918? Transylvania could likewise be thought of as the part of Central-Eastern Europe that straddles the border between East and West. In truth, however, in every sense of the term, this region is a "core" region rather than a "borderland." As Lucian Nastasa points out in another context, "it must be reiterated that Transylvania was for both Romania and Hungary the core of the national movement, starting with the second half of the nineteenth century (368)." Unlike the two other editors of the volume, Blomqvist is also less careful in the use of sweeping and biased statements. For example, he claims that with the return of Northern Transylvania to Hungary in 1940, Hungarian Prime Minister Pál Teleki "implemented a new wave of re-Magyarization" (170), a claim that totally misrepresents Teleki's policy. In every statement he made on the re-aquisition of former Hungarian territories, Teleki stressed that Hungarians must not commit the same mistake of exlusion and persecution of minorities twice, and that tolerance and safeguarding of minority rights must be the guidelines of Hungarian policy. Furthermore, Teleki would not have had the time for re-Magyarization, as he committed suicide in April 1941, when the German military used Hungarian territory to attack Yugoslavia. Surely, the last eight months of his life were dedicated to more important issues than to implementing failed policies which he himself had come to see as ineffective.

The remaining studies in the volume are less comprehensive, i.e., more limited in scope, in terms of either topic or time period. This is the case for the essays written by Judith Pál, Barna Abraham, Gábor Egry, Tom Kowol, Marius Turda, Ottmar Trasca, Holly Case, Katalin Miklóssy and Michael Shafir. Each one adds something to the overall analysis, in most instances with objective intentions and a clear readable style; yet, in several instances this is done with somewhat impaired objectivity. For example, Shafir's essay on "Reconciliation at the Wrong 
Ludanyi, Andrew. "Blomqvist, Anders E. B., Constantin Iordachi, Balázs Trencsényi (eds.) 2013. Hungary and

Romania Beyond National Narratives - Comparisons and Entanglements in Nationalisms Across the Globe."

Hungarian Cultural Studies. e-Journal of the American Hungarian Educators Association, Volume 7 (2014):

http://ahea.pitt.edu DOI: 10.5195/ahea.2014.153

End," which has all the earmarks of objectivity, with proper quotes and footnotes throughout, still has a general tone of "attack journalism." Thus, Shafir uses the tragic death in 2009 of the Romanian handball player Marian Cosma, who was killed by Roma hulligans in Hungary, to "demonstrate" that Hungarians and Romanians are united by their racism, when this tragic incident is hardly an example of his claim. Furthermore, Shafir picks up on the writings of Zsolt Bayer's racism and links them to a number of Romanian authors (including Cristian Tudor Popescu and Horia-Roman Patapievici), who have expressed solidarity with Bayer's articles. In short, Shafir presents Romanians and Hungarians as moving closer to each other because of their common racist commitments, implying that this is characteristic of the two societies and their leaderships. In the case of Bayer he explicitly links present-day Prime Minister Viktor Orbán to this stance (thereby ignoring the fact that Orbán has done more to fight racism and anti-Semitism than any of his predecessors, or for that matter, any of the EU member states; the EU "Roma Year" in 2010 was initiated by the Orbán administration and so was the global Holocaust conference in Budapest in 2014). The point is, without even considering the merits of such accusations, that a scholarly volume is not the place to lash out an attack on a contemporary political administration. Scholarship and "attack journalism" cannot co-exist under the same cover.

Despite such problems, I highly recommend the Blomqvist, Iordachi and Trencsényi volume to scholars of Eastern and Central Europe and of Romanian-Hungarian relations. It is also a good introduction for graduate students seeking a thorough overview as well as fine analyses of interstate relations in the age of nationalism. However, the reader should be forwarned that the collection does have an unstated underlying thesis that national sentiments and nationalism as a factor are a threat to stability and peace. Nationalism is viewed not as a phenomenon that can have both positive and negative consequences, but only as one that poses a threat. In the framework of today's complex and varied considerations of nationalism, this unanimous stance is questionable. Yet, as stated, the volume as a whole is of contribution and deserves scholarly attention. 